\title{
FINANCIAL CAPABILITY AND TECHNOLOGY IMPLICATIONS FOR ONLINE SHOPPING
}

\section{Gentjan Çera ${ }^{1}$, Quyen Phu Thi Phan ${ }^{2}$, Armenia Androniceanu ${ }^{3}$, Edmond Çera ${ }^{4}$}

1 Tomas Bata University in Zlin, Faculty of Management and Economics, Czech Republic, ORCID: 0000-0002-9324-181X, cera@utb.cz;

2 The University of Danang, University of Economics, Faculty of Marketing, Vietnam, ORCID: 0000-0002-4048-1369, phuquyen.due@gmail.com;

3 Bucharest University of Economic Studies, International Centre for Public Management, Romania, socialsciences723@gmail.com;

4 Tomas Bata University in Zlin, Faculty of Management and Economics, Czech Republic, ORCID: 0000-0003-3546-2101, ecera@utb.cz.

\begin{abstract}
To promote online shoppers' long-term interest, consumers need to have the knowledge and ability to avoid problems with financial issues. Financial capability helps to put consumers on the path to a sustainable financial future. However, previous studies only focused on financial capability in a financial context. To handle personal finance systematically and successfully in an online setting, this study extends an enhanced understanding of how financial capability on online consumer behaviour. Based on the data of 690 respondents collected by a face-to-face from eight main regions in Albania, this study employed principal components analysis and logistic regression in order to investigate the effect of consumers' financial capabilities and technology use on the decision to purchase online. The outcome of this study firstly identifies six dimensions of financial capabilities, namely, digital banking usage, financial service risk, financial advice, payment risk, risk tolerance, and financial attitude. Secondly, the finding revealed that individuals who use smartphones and administrate a social media account, are more likely to involve in purchasing through online channels. Moreover, the decision to purchase online is more prone for those individuals who manifest high levels in digital banking usage, financial advice, prior bank experience and technology usage, and low levels in attitude towards payment risk and attitude towards risk tolerance. This paper offers useful insights concerning the determinants of online purchasing by combining individuals' financial capability, technology and social media usage along with its demographic characteristics. In term of practical contribution, this study provides a useful model by incorporating for measuring and managing consumers' financial capability to enhance their involvement and to reduce their cognitive dissonance in the online shopping context. This study also contributes to the accumulated knowledge and encourages consumers to use digital banking and consult their financial issues when purchasing online.
\end{abstract}

Keywords: Financial capability, logistic regression, online shopping, prior bank experience, smartphone, social media.

JEL Classification: G53, D91.

APA Style Citation: Çera, G., Phan, Q. P. T., Androniceanu, A., \& Çera, E. (2020). Financial Capability and Technology Implications for Online Shopping. E\&M Economics and Management, 23(2), 156-172. https://doi.org/10.15240/tul/001/2020-2-011

\section{Introduction}

The Internet plays a vital role in our daily life in that people can easily access our world and open international borders. Meanwhile, online shopping has been widely accepted as a way of purchasing products and services. It provides a dominant alternative to traditional retail shopping. Consumers can search for more 
information and select to compare product and price, more options, convenience. Online shopping offers more satisfaction to consumers save time (Katawetawaraks \& Wang, 2011). However, the investigation of online consumer behaviour is relatively underdeveloped (Smith et al., 2013). Although online shopping behaviour is not a new topic, the unanswered question that what determines consumers' willingness to purchase a product online have attracted many researchers. In this line of study, researchers identified factors influencing on purchase behaviour of the consumer based on Theory Planned Behavior (Ajzen, 1991), Technology Acceptance Model (Davis, 1989), Stimulus-Organism-Response (Mehrabian \& Russell, 1974). The first approach focused on the direct impact on consumer behaviour. For example, Wu and Ke (2015) integrated a model of personality traits, perceived risk and technology acceptance in online shopping behaviour. Another approach focused on the indirect impact of attitude, trust on consumers' purchase behaviour (Al-Debei, Akroush, \& Ashouri, 2015; Belás \& Gabčová, 2016; Oluwafemi \& Adebiyi, 2018). Nevertheless, both approaches focus on consumers' behavioural intention as a predictor of actual purchase behaviour. This study explores (the direct impact of consumers' financial capability on their actual purchase decisions) consumers' actual purchase decisions and its antecedents.

Recently, it is acknowledged that with the rise of service delivery, in general, and online shopping, in particular, some other aspects (such as security, trust and perceived risk) have become key issues for online behaviour (Kim, Ferrin, \& Rao, 2008; Mou, Shin, \& Cohen, 2017; Silva, Pinho, Soares, \& Sá, 2019; Suchanek \& Kralova, 2018). However, there is limited attention relating to consumers' financial matters while many customers have had very little understanding of finances, how credit works and the potential financial risk (Lusardi \& Mitchell, 2014).

Unlike previous research, this study focuses on the potential effect of consumer financial capability on their online purchase decisions. Additionally, in the field of consumer finance, previous studies focused on the influence of financial capability on consumers' behaviour toward financial products/service. In this study, we argue that customers' knowledge and understand about financial matters play a vital role in their purchase decision towards all products, not only towards financial products. Therefore, in the authors' knowledge, this is the first study that investigates the relationship between consumers' financial capability on consumers' purchase decisions generally in the online context.

Financial capability captures people's knowledge of financial matters, their ability to manage their money and to take control of their income. Based on Sen's capability theory (1993), financial capability refers to the ability to act (e.g. people's knowledge, skills, attitudes, habits, motivations, confidence and selfefficacy), and opportunity to act (e.g. people's awareness of basic financial products they need to manage their money lives) (Collard, 2019). Previous studies of financial capability used specialist surveys (Atkinson, McKay, Kempson, \& Collard, 2006; Kempson, Collard, \& Moore, 2005; Taylor, 2011). Adopting Sen's capability theory (1993), our paper extends existing knowledge about the potential approach of measuring key components of financial capability that relate to consumers' knowledge, attitudes toward risk and financial matters, financial management using responses to survey questions in a bank survey about consumers' actual shopping behaviour. While most of the previous studies merely focused on financial capability in financial decision making, this research makes an important contribution to the current literature by extending our knowledge of financial capability on consumer online shopping decision making.

In addition, to study the online shopping topic, technology and social media usage have come into the scholars' attention (Hubert, Blut, Brock, Backhaus, \& Eberhardt, 2017; Pucci, Casprini, Nosi, \& Zanni, 2019). To be able to predict the effects of technology usage on online purchasing, previous studies often explored the acceptance of technology (Hubert et al., 2017); and several studies focused on specific technologies such as a smartphone (Voropanova, 2015), social media (Mikalef, Giannakos, \& Pateli, 2013). However, less is known about the reasons that influence consumers' actual online shopping about the wide ranges of technologies available to them in their everyday lives. This study focuses on two types of technologies, namely, smartphone and social media. Additionally, except for age, gender, income, occupation as control 
variables, this study explores the impact of other demographic (e.g. prior banking experience) on online shopping. The widespread adoption of the banking sector is strongly linkage in the overall online environment (Hamidi, Rad, \& Jahany, 2012), customer with more banking experience tend to choose the Internet as a platform for shopping. However, the impact of prior banking experience on actual online purchase has not been thoroughly investigated. The current study also fills this gap in the literature.

Furthermore, most of the studies in online shopping pivoted on the developed countries' markets. Very limited research has been conducted in the context of investigating online consumer behaviour across transition countries. Obliviously, different online factors influence online consumers' behaviour depending on the environment of different regions. Albania is one of the transition countries and Albania consumers are more flexible. A report of Information and Communication Technology (ICT) in Albania (2019) showed that online purchases are carried out by $10.1 \%$ of the population aged 16-74 years old. However, it is interesting that more than $90 \%$ of the transaction in Albania witness cash transaction and a big chunk of the population does not have a bank account. This leads a doubt that a low credit card usage in Albania is the underlying reason for a low online purchasing power. This study argues that consumers may be motivated online shopping by their financial knowledge and abilities in avoiding problems with financial issues. For these reasons, it is valuable to focus on the analysis of online consumers in Albania under the impact of financial capabilities.

Based on the above gaps, this study focused on two main objectives. First, with the Sen's capability theory (1993), this study identifies variables in the bank survey of online consumers that are relevant to three key contributory factors in financial capability knowledge, attitude, and money management. Then, this study investigates the effect of these dimensions on online shopping. Secondly, this study examines the impacts of technology usage (e.g. social media, smartphone) and prior bank experience on consumers' actual shopping behaviour in a transition country context, e.g. Albanian.

This study makes significant contributions to the extant literature. Firstly, this study contributes to the literature of online consumer behaviour by exploring the potential role of financial capability, technology usage, and prior bank experience on actual shopping behaviour. This study also contributes to the literature of financial capability by using a unique set of variables to measure financial capability. This can be informative for online vendors to develop effective financial strategies to help tackle consumer financial matters when shopping online.

Next part of this paper is dedicated to the literature review and hypotheses development. Further part describes data collection, variable measurement and the used method. The results are analysed and interpreted under the section named 'results'. Then, our findings are discussed. At the end of the paper, the conclusions are presented.

\section{Theoretical Background}

Consumers always find out their best decisions given that they have a limited budget of money. While purchasing products/service from a shop, consumers have to spend both money and time. With the phenomenon of Internet shopping today, the time cost has almost eliminated. However, as truly stated that nothing comes without a cost in business. When consumers have unlimited choice, they spend a lot of time without making any final decision. The biggest reason is that there is no "touch and feel factor" in an online shopping context, therefore, consumers are based on the price in their purchase. Meanwhile, they feel no safe when purchasing products via credit cards (Bilgihan \& Kandampully, 2016). Generally, most studies pointed out that financial issues (financial risk, how to use a credit card, how to spend money to purchase among unlimited choice) always are consumers' issues when purchasing online.

Financial capability is a relatively new construct emerged in the last decade. According to Sen's capability theory (1993), financial capability refers to people's ability with the right sorts of knowledge, skills, attitude, habits, motivation, as well as their opportunity toward accessing the basic financial products and service that are equipped to manage their financial matters. Similarity, Taylor (2011) defined that financial capability refers to people's knowledge to manage and take control of their finances. This concept mentions making appropriate financial decisions, understanding how to control credit and debt, and identifying 
products and services that are appropriate (Xiao, Chen, \& Chen, 2014). However, Despard and Chowa (2014) pointed out that the concept of financial capability and financial literacy are often understood interchangeably. While Huston (2010) defined financial literacy as the description of financial knowledge, McKay (2011) described that financial capability focuses on financial behaviour and reflects to putting financial knowledge into action, which is linked with Huston's (2010) definition. In first glance, both of definition, financial capability and financial literacy are similar ways (Çera \& Tuzi, 2019; Nguyen \& Rozsa, 2019; Shkvarchuk \& Slav'yuk, 2019). However, Sherraden (2013) indicated that financial literacy assumes that individuals all have equal chances to enhance financial knowledge and skills, but the financial capability assumes that not all may have the same chances. Additionally, financial capability is formed through interaction with and feedback from the environment. In the online context, consumers' financial knowledge and skills are shaped in online communities. Therefore, based on Sen's capability theory (1993), the concept of financial capability that is defined as consumers' knowledge, attitude and their financial management in this study.

Some scholars have developed the conceptual model and empirical tests of financial capability. The first study of financial capability was conducted by the Financial Services Authority (FSA) in the UK (Atkinson et al., 2006). This research identified five different constructs of financial capability, such as: (1) making ends meet: reduce problems in financial obligations, (2) managing money: keeping track with control an overview of expenses, (3) planning ahead: being futureoriented, (4) selecting products, e.g. deciding reasonably in financial matters, and (5) staying informed, e.g. searching information about financial products. All factors were described closely with financial behaviours. Then, Taylor (2011) developed a measurement of financial capability based on a combination of behaviour and outcome constructs. Specifically, he explored seven variables in financial capability. There are four statements of financial outcomes, such as (1) difficulties in spending accommodation, (2) borrowing to meeting housing payments, (3) make cutback, (4) found yourself for two months behind with your rent/ mortgage, (6) Would you say that you are better off, worse off or about the same financially than you were a year ago? Additionally, there are two statements of financial behaviours, such as: (5) how well would you say you are managing financially these days, and (7) "save any amount of your income". Furthermore, Xiao et al. (2014) measured financial capability with three constructs, perceived financial capability, financial literacy, and financial behaviour. Despard and Chowa (2014) examined financial literacy and financial inclusion as a combination of financial capability. The study is to extend existing knowledge about potential ways of measuring key components of financial capability that related to consumers' knowledge and understanding of financial matters, including their ability to take control about finances, their attitude of financial risk (Taylor, 2011), their knowledge about financial providers, as well as financial counsellors (informal source, e.g. family, friends, newspaper; and formal source, e.g., financial advisor, banker) that they use to gain financial knowledge (Vyvyan, Blue, \& Brimble, 2014).

Consumers today are increasing the use of online and digital environments for shopping and making financial transactions under an uncertainty environment. The increase in Internet access and the growth of Internet banking have led to a dramatic rise in purchasing goods and services on the Internet (MCEETYA, 2011). Consumers are responsible for making decisions in the online context. They need to enhance their capabilities in solving their financial issues and plan for needs and wants. Lam and Lam (2017) argued that consumers that are more likely to take control of their financial situation reflect their buying behaviour and expenditures. Duroy, Gorse and Lejoyeux (2014) noted that scholars should focus on consumers' financial behaviour in online consumer behaviour because of different Internet-related behaviours and offline shopping. Shopping on the Internet is highly risky regarding the payment process via e-banking. Customer may face security and privacy problems on the Internet. These risks may increase because consumers are concerned about the security of transmitting credit card information through the Internet. Additionally, to gain financial knowledge, most consumers base on a large amount of information and advice consultants, consisting of informal sources (i.e. family, friends) or 
formal sources (i.e. financial advisors or bankers) before conducting their purchasing decisions (MCEETYA, 2011). Based on the above discussion, the hypothesis is:

H1: Consumers' financial capability affects online shopping.

A major concern among all internet consumers is that they must face a higher risk than traditional shopping if they are using stolen credit cards or fraudulent repudiation of the online purchase. Banks must adjust their priorities to respond to this transformational shift in the way consumers do their banking, given that the user can economize on time and effort. Although customers can select the cash on delivery (COD) in online purchasing; however, Hamidi et al. (2012) indicated that e-banking has prominently impacted consumers' purchasing behaviour. He explained that customers can use online banking for making transactions by debit card or credit card, even when they have no ready cash as long as they have their mobile line linked to their bank account (Belás, Cipovová, \& Demjan, 2014; Negash, Meso, \& Wiredu, 2011). There is no doubt about the role of e-banking that is greatly affecting consumers' purchase decisions. Consumers who have experience in the online payment process have splendidly increased the way people pay for their bills. Based on the above discussion, we argue that customers who have experience in bank usage are much more comfortable with online banking in online shopping. Therefore, we hypothesize that:

H2: Individuals' prior bank experience positively influences online shopping.

Social media and smartphone change both the way consumers interact and consumer information and how companies communicate with consumers and deliver their services. When consumers have begun using Internetenabled multi-devices and social networking sites, there has been a considerable increase and transfer in online shopping behaviour (Wagner, Schramm-Klein, \& Steinmann, 2013).

First of all, the phenomenon of social media has fundamentally changed how many people, communities and companies communicate and interact. Kaplan and Haenlein (2010) defined social media as "a group of Internetbased applications that build on the ideological and technological foundations of Web 2.0, and allow the creation and exchange of user generated content". In the area of business, social media has opened up a new area of electric commerce, called social commerce, which changes the manner we define online shopping. Social commerce is formed on different types of social media, such as Facebook, Instagram, Youtube, and Twitter. Social media have fundamentally changed the consumer decision process when it provides personalized service and product delivery based on consumer preferences, interest, and interactions with other consumers and friends (Gibreel, AlOtaibi, \& Altmann, 2018). Previous studies indicated that one of the reasons why consumers go shopping is due to the enjoyment which the social interaction provides (Mikalef et al., 2013). When users log on the social media platform, they have the opportunity to explore the brand pages, comments, shares a photo, or experience (Laroche, Habibi, \& Richard, 2013). For instance, consumer reviews are widely available for products and services on the social media platform, helps consumers in their purchasing decisions (Pan \& Chiou, 2011).

At the same time, smartphones are also the predominant driver of growth of mobile e-commerce transactions. More than a third of all e-commerce transactions are performed via mobile devices nowadays (CRITEO, 2018). Consumers use a smartphone to purchase product and services over a wireless telecommunication network (Hubert et al., 2017). Consumers can perform a purchase online using their mobile device. A report indicated that consumers who have smartphones are more likely to shopping than others who don't use a smartphone (Shechter, 2017). In fact, consumers can access the service through the e-retailers from a computer or by using their mobile phones to download free apps (called as m-commerce), which offers the same functionalities as the website. They can purchase products through the mobile app and then collect them in the closest store. On the other hand, consumers are browsing and buying across all channels and more active on mobile devices than ever (CRITEO, 2018). Based on the line of argument, we hypothesize that:

H3: Consumers who have social media account have higher chances to purchase online.

H4: Individuals who use a smartphone have higher chances to purchase online. 


\section{Research Methodology}

The unit of analysis in the current research is an individual who uses or has tried online shopping. The data used in this article were collected by a face-to-face interview survey, which was conducted in eight main regions in Albania during spring 2018. Random route and last birthday method were applied in the process of the respondent's selection. Only 690 respondents out of all successful interviews of the survey were considered for further data processing.

Online shopping was the dependent variable employed in this research measured as a single-item: I use or have tried online shopping. It takes two possible values: $1=$ yes, or $0=$ no, making it a dichotomous variable. The measurement type of this variable limits the statistical method that should be performed to explore the determinants of individuals' online purchase decision. Half of the respondents $(52.2 \%)$ used or have tried online shopping.

Prior bank experience was measured as the number of years one was a client of a bank (categorical variable: less than 1 year; 1-2 years; 3-5 years; 5-10 years, and over 10 years). The current research employed two main sets of independent variables: technology use and individuals' financial capability. Technology use was covered by two variables, which are related to the fact whether an individual has or not a smartphone and social media account. Similar to the dependent variable, these variables had two possibilities:

$1=$ yes, 0 = otherwise. More than eighty per cent of respondents were reported to possess a smartphone $(89 \%)$ and administrate a social media account (85\%).

Individual's financial capability was measured using sixteen statements related to peoples' knowledge, attitude, and money management, which were defined by Sen's capability theory (1993). Individuals were asked to give their perception of these statements (see Tab. 1). The statements' responds were formulated as five-point Likert type scale $(1=$ not at all, $5=$ fully agree $)$. Factor analysis was used to reduce this huge number of factors. The principal component analysis helped summarise individual's perceptions about sixteen statements into a smaller number of underlying factors. We have kept factors with eigenvalues higher than one. The rotated component matrix is reported in Tab. 1. Six factors emerge from the performed factor analysis, which explained $58.5 \%$ of the variance in the sample. The first factor combines statements related to credit cards and online banking, which we called digital banking usage, which corresponds with Mbama et al.'s (2018, p. 434) definition, that includes "electronic banking services via digital devices (e.g. t-banking, e-banking, m-banking, contactless card (e.g. tap and go), ATM and point-ofsale) [...] to interface with banks". Moreover, it is consistent with what Sherraden (2013) claims that financially capable individuals have access to beneficial financial products and services, besides other characteristics. Thus, it is expected that individuals who have higher digital banking usage to have higher chances to purchase online (H1a). The second factor combines three items about the attitude towards financial service risk, which is consistent with the Estelami and De Maeyer's (2010) discussion that bank account users manifest a certain level of risk dealing with financial services. Individuals who perceived lower financial services risk are expected to get involved in online shopping activity (H1b). The third factor combines responses about the need to consult on taking financial decisions, which we named financial advice, as elaborated by prior studies (Calcagno \& Monticone, 2015; Kramer, 2016; Marsden, Zick, \& Mayer, 2011). Individuals who consult or seek for advice on financial matters have higher chances to purchase via online channels $(\mathrm{H} 1 \mathrm{C})$. The fourth factor is a combination of two items which points at the risk of using the bank to pay bills. Therefore, this factor is called attitude towards payment risk. People who perceive high payment risk are less prone to high-risk payment methods (Hove \& Karimov, 2016). As a result, a negative association is expected between payment risk and online shopping (H1d). The fifth factor combines two statements and we named it attitude towards risk tolerance, which goes in line with Joo and Grable's (2004) scale. The higher the level of this component, the lower the chances individuals involve in online purchase activity $(\mathrm{H} 1 \mathrm{e})$. Finally, the sixth underlying factor is a combination of two items, and it is called financial attitude. A study used a similar but larger scale to test the influence of financial attitude on compulsive buying (Pham, Yap, \& Dowling, 2012). Online shopping is expected 


\begin{tabular}{|c|c|c|c|c|c|c|}
\hline Item and component & 1 & 2 & 3 & 4 & 5 & 6 \\
\hline Digital banking usage & & & & & & \\
\hline $\begin{array}{l}\text { I like trying new trends in banking - e.g. internet banking, } \\
\text { mobile payments, paying by credit cards in the store etc. }\end{array}$ & .814 & & & & & \\
\hline $\begin{array}{l}\text { I use online banking whenever I have the chance and } \\
\text { opportunity to use }\end{array}$ & .734 & & & & & \\
\hline $\begin{array}{l}\text { I proactively seek for the information regarding different banking } \\
\text { products \& services }\end{array}$ & .636 & & & & & \\
\hline I cannot imagine my life without banking & .515 & & & & & \\
\hline Attitude towards financial service risk & & & & & & \\
\hline $\begin{array}{l}\text { I feel that banks do not inform the customers well about all the } \\
\text { details and costs of bank products/services }\end{array}$ & & .812 & & & & \\
\hline Banks want to exploit you, they think only about their profit & & .751 & & & & \\
\hline $\begin{array}{l}\text { I have sometimes problems to understand the details of banking } \\
\text { products and bank language in general }\end{array}$ & & .642 & & & & \\
\hline Financial advice & & & & & & \\
\hline Spending too much money makes me feel guilty & & & .688 & & & \\
\hline I consult my financial matters with a financial advisor or banker & & & .654 & & & \\
\hline I consult my financial matters with family, friend etc. & & & .625 & & & \\
\hline Attitude towards payment risk & & & & & & \\
\hline $\begin{array}{l}\text { I prefer to visit the branch personally when I want to do some } \\
\text { bank transaction }\end{array}$ & & & & .705 & & \\
\hline $\begin{array}{l}\text { I don't pay my utilities through banks as I trust only stamped } \\
\text { receipts about payment from utilities themselves }\end{array}$ & & & & .676 & & \\
\hline Attitude towards risk tolerance & & & & & & \\
\hline I keep my money at home rather than in the bank & & & & & .705 & \\
\hline $\begin{array}{l}\text { My relationship with the bank is "only getting my salary" through } \\
\text { ATMs }\end{array}$ & & & & & .690 & \\
\hline Financial attitude & & & & & & \\
\hline I'm trying not to have any debts & & & & & & .864 \\
\hline I always keep some savings for unpredictable future expenses & & & & & & .624 \\
\hline
\end{tabular}

Note: Rotation method: Varimax with Kaiser normalization. Rotation converged in 6 iterations; Kaiser's measure of sampling adequacy $=.686$; Variance explained $=58.546 \%$; Correlation matrix's determinant $=.136$; Coefficient loading displayed $>|.34|$.

to be positively affected by individuals' financial attitude (H1f).

Given that the demographic variables of age, gender, education, and income have been found to have a significant effect on consumers' online purchasing behaviour (Naseri \& Elliott, 2011; Oertzen \& Odekerken-Schröder, 2019; Prasad \& Sharma, 2016; Punj, 2011). These demographic variables were included as control variables in the analysis to avoid potential causal influence on online shopping behaviour. Considering the identified linkages in the literature review and the result of the factor analysis, a conceptual framework can be framed as it is illustrated in Fig. 1. 


\section{Fig. 1: Conceptual framework}

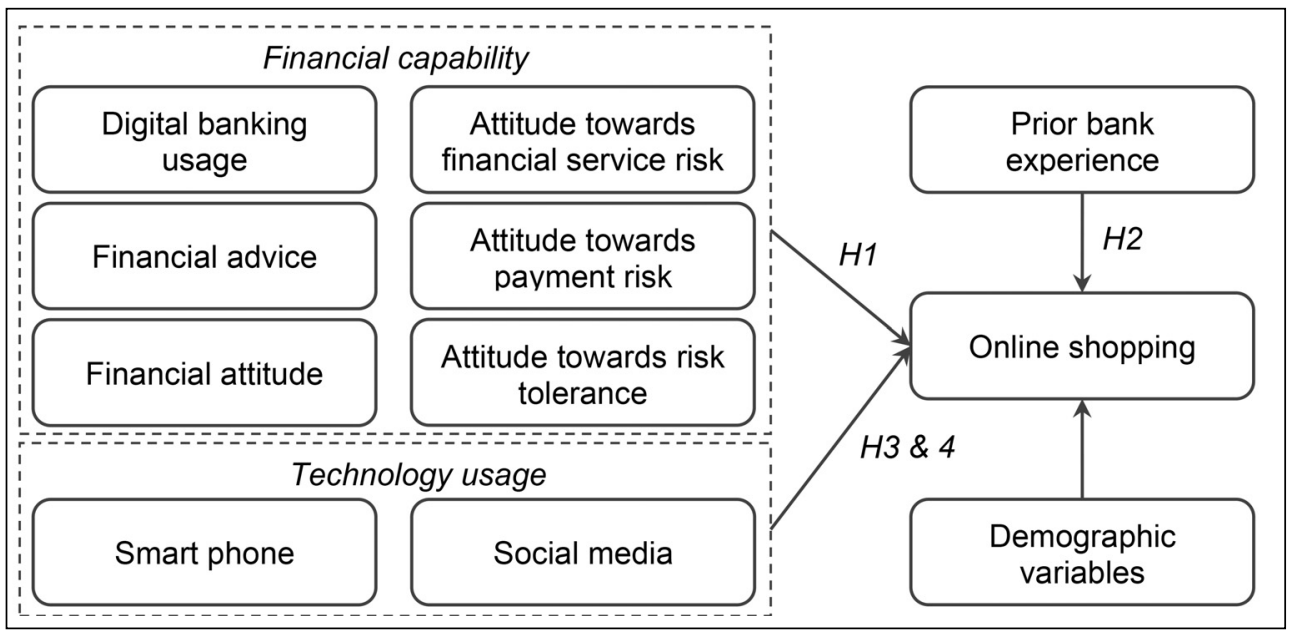

Source: own

As mentioned earlier, the nature of the dependent variable limits the use of the statistical method. With this in mind, logistic regression was performed to investigate the effect of consumer's financial capabilities and technology use on the decision to purchase online (Hosmer, Lemeshow, \& Sturdivant, 2013; Tabachnick \& Fidell, 2013). All the analyses shown here are performed using computer statistical packing SPSS, version 23.

\section{Research Results}

To have a better view of the effect of different factors on our dependent variable, four logistic regressions were performed. In all cases, the dependent variable was online shopping (Yes/No). The first one (Model 1, baseline model), includes only control variables, which were gender, age, income level and occupation of the respondent. The second model includes two factors related to technology use, which are having a smartphone and using social media. The results of these two logistic regressions are shown in Tab. 2. Model 3 and 4 intend to investigate the effect of consumer's financial capabilities and prior bank experience on online shopping. Their results are summarized in Tab. 3.

The baseline model demonstrated that besides gender, all other controlled variables have a statistically significant influence on online purchase decision (see Tab. 2). Older individuals had fewer chances to get involved in online shopping, as the odds ratio was reported less than one, $X^{2}=44.23, \mathrm{OR}=0.947, p<0.01$. As the individual's income level increases, the higher are the odds ratios he/she purchased online. When compared to the highest income level, the income levels were statistically significant, indicating that income predicted one's online purchase decision, for example, the third level, $X^{2}=7.195$, OR $=0.181, p<0.01$. Referring to an individual's occupation, results showed that managers or self-employed had higher chances to purchase online, $X^{2}=6.769$, $\mathrm{OR}=4.367, p<0.01$. Similar results are found even for those working as specialists, $X^{2}=5.299$, OR $=3.525, p<0.05$. Therefore, occupation statistically predicted online shopping, $X^{2}=19.19, p<0.01$.

Model 2 explores the relationship of online shopping with technology use by including in the analysis of the two new variables: having a smartphone and using social media (see Tab. 2). This logistic regression revealed that both variables predicted an individual's online purchase decision. Possessing a smartphone $\left(X^{2}=5.604, O R=4.773, p<0.05\right)$ and using social media $\left(X^{2}=17.61\right.$, OR $\left.=9.564, p<0.01\right)$ increased the chances that an individual 


\begin{tabular}{|c|c|c|c|c|c|c|c|c|c|c|}
\hline \multirow[t]{3}{*}{ Tab. 2: } & essio & s' res & Its: th & effec & & tolos & & & pur & \\
\hline & \multicolumn{5}{|c|}{ Model 1 (baseline) } & \multicolumn{5}{|c|}{ Model 2 (technology use) } \\
\hline & B & SE & OR & Wald & & B & SE & OR & Wald & \\
\hline Constant & 2.387 & 0.885 & 10.88 & 7.275 & $* * *$ & -2.097 & 1.223 & 0.123 & 2.940 & * \\
\hline Gender & -0.030 & 0.177 & 0.970 & .0280 & & 0.066 & 0.190 & 1.068 & 0.123 & \\
\hline Age & -0.054 & 0.008 & 0.947 & 44.23 & *** & -0.021 & 0.010 & 0.979 & 4.653 & ** \\
\hline Income & & & & 9.870 & & & & & 7.364 & \\
\hline Less than $15,000 \mathrm{ALL}$ & -2.209 & 0.809 & 0.110 & 7.458 & *** & -1.937 & 0.866 & 0.144 & 4.998 & ** \\
\hline 15,000-23,999 ALL & -1.950 & 0.666 & 0.142 & 8.576 & $* \star \star$ & -1.565 & 0.724 & 0.209 & 4.666 & ** \\
\hline 24,000-39,999 ALL & -1.709 & 0.637 & 0.181 & 7.195 & $* * *$ & -1.587 & 0.687 & 0.205 & 5.328 & ** \\
\hline 40,000-59,999 ALL & -1.575 & 0.633 & 0.207 & 6.189 & ** & -1.655 & 0.677 & 0.191 & 5.971 & ** \\
\hline 60,000-78,999 ALL & -1.588 & 0.691 & 0.204 & 5.286 & ** & -1.840 & 0.733 & 0.159 & 6.296 & ** \\
\hline $79,000-100,000 \mathrm{ALL}$ & -1.692 & 0.811 & 0.184 & 4.355 & ** & -1.874 & 0.840 & 0.154 & 4.979 & ** \\
\hline Occupation & & & & 19.19 & $* * *$ & & & & 9.880 & ** \\
\hline Manager or self-employed & 1.474 & 0.567 & 4.367 & 6.769 & *** & 1.036 & 0.620 & 2.818 & 2.786 & * \\
\hline Specialist & 1.260 & 0.547 & 3.525 & 5.299 & ** & 1.012 & 0.608 & 2.751 & 2.775 & * \\
\hline Unqualified worker & 0.236 & 0.590 & 1.266 & 0.161 & & 0.166 & 0.657 & 1.181 & 0.064 & \\
\hline Education & & & & & & & & & 6.737 & * \\
\hline Elementary & & & & & & -1.672 & 0.805 & 0.188 & 4.314 & ** \\
\hline Vocational & & & & & & -0.033 & 0.462 & 0.968 & 0.005 & \\
\hline Secondary & & & & & & -0.408 & 0.220 & 0.665 & 3.421 & * \\
\hline \multicolumn{11}{|l|}{ Technology use } \\
\hline Smartphone & & & & & & 1.563 & 0.660 & 4.773 & 5.604 & ** \\
\hline Social network & & & & & & 2.258 & 0.538 & 9.564 & 17.61 & *** \\
\hline Model test/statistic & & $x^{2}$ & $d f$ & Sig. & & & $x^{2}$ & $d f$ & Sig. & \\
\hline Omnibus test & & 86.76 & 11 & 0.000 & & & 151.6 & 16 & 0.000 & \\
\hline Hosmer \& Lemeshow test & & 10.54 & 8 & 0.229 & & & 5.715 & 8 & 0.679 & \\
\hline -2Log likelihood & 762.5 & & & & & 697.7 & & & & \\
\hline Cox \& Snell $\mathrm{R}^{2}$ & 0.132 & & & & & 0.218 & & & & \\
\hline Nagelkerke $\mathrm{R}^{2}$ & 0.176 & & & & & 0.292 & & & & \\
\hline Observations & 615 & & & & & 615 & & & & \\
\hline
\end{tabular}

Source: own

Note: ${ }^{*},{ }^{* *}$, and ${ }^{* * *}$ stand for $90 \%, 95 \%$ and $99 \%$ significance level. Levels of income are compared to Income above $100,000 \mathrm{ALL}$ (1 EUR = 126.89 ALL, 10th May 2018), occupation categories are compared to Other category, education levels are compared to the university one.

purchase through online channel. As a result, $\mathrm{H} 3$ and $\mathrm{H} 4$ were supported. Concerning control variables, Model 2 showed similar results with the baseline model. Moreover, Model 2 included education level as an extra control variable, which was found to be significant, $X^{2}=6.737$, $p<0.10$. Thus, the higher the education level, the higher were the odds an individual to purchase online.

As mentioned earlier, Model 3 and 4 are performed to investigate the effect of individuals' financial capability and experience as a bank client on online shopping. Their results are shown in Tab. 3 . Model 3 is an 


\begin{tabular}{|c|c|c|c|c|c|c|c|c|c|c|}
\hline & \multicolumn{5}{|c|}{ Model 3 (financial capability) } & \multicolumn{5}{|c|}{ Model 4 (prior bank experience) } \\
\hline & B & SE & OR & Wald & & B & SE & OR & Wald & \\
\hline Constant & -1.892 & 1.365 & 0.151 & 1.921 & & -0.911 & 1.501 & 0.402 & 0.368 & \\
\hline Gender & -0.150 & 0.209 & 0.861 & 0.512 & & -0.111 & 0.218 & 0.895 & 0.261 & \\
\hline Age & -0.018 & 0.011 & 0.982 & 2.596 & & -0.027 & 0.013 & 0.973 & 4.326 & ** \\
\hline Income & & & & 6.121 & & & & & 9.328 & \\
\hline Less than $15,000 \mathrm{ALL}$ & -1.709 & 0.926 & 0.181 & 3.409 & * & -1.922 & 0.955 & 0.146 & 4.054 & ** \\
\hline 15,000-23,999 ALL & -1.428 & 0.785 & 0.240 & 3.311 & * & -1.265 & 0.805 & 0.282 & 2.469 & \\
\hline $24,000-39,999$ ALL & -1.245 & 0.745 & 0.288 & 2.794 & * & -1.101 & 0.763 & 0.333 & 2.081 & \\
\hline 40,000-59,999 ALL & -1.433 & 0.730 & 0.239 & 3.856 & ** & -1.516 & 0.747 & 0.220 & 4.116 & ** \\
\hline 60,000-78,999 ALL & -1.714 & 0.802 & 0.180 & 4.568 & ** & -1.815 & 0.820 & 0.163 & 4.897 & ** \\
\hline 79 000-100,000 ALL & -1.691 & 0.898 & 0.184 & 3.548 & * & -1.865 & 0.908 & 0.155 & 4.217 & ** \\
\hline Occupation & & & & 5.474 & & & & & 5.031 & \\
\hline Manager or self-employed & 0.592 & 0.709 & 1.808 & 0.698 & & 0.215 & 0.732 & 1.240 & 0.086 & \\
\hline Specialist & 0.761 & 0.692 & 2.140 & 1.209 & & 0.424 & 0.714 & 1.528 & 0.353 & \\
\hline Unqualified worker & 0.040 & 0.742 & 1.041 & 0.003 & & -0.336 & 0.765 & 0.715 & 0.193 & \\
\hline Education & & & & 3.590 & & & & & 3.678 & \\
\hline Elementary & -1.447 & 0.889 & 0.235 & 2.651 & & -1.360 & 0.922 & 0.257 & 2.177 & \\
\hline Vocational & 0.357 & 0.484 & 1.429 & 0.545 & & 0.463 & 0.489 & 1.589 & 0.896 & \\
\hline Secondary & -0.128 & 0.246 & 0.880 & 0.271 & & -0.150 & 0.254 & 0.861 & 0.347 & \\
\hline \multicolumn{11}{|l|}{ Technology usage } \\
\hline Smart phone & 2.280 & 0.578 & 9.773 & 15.53 & 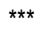 & 2.386 & 0.587 & 10.87 & 16.54 & *** \\
\hline Social network & 1.465 & 0.723 & 4.330 & 4.109 & ** & 1.505 & 0.727 & 4.504 & 4.285 & ** \\
\hline \multicolumn{11}{|l|}{ Financial capability } \\
\hline Digital banking usage & 0.911 & 0.122 & 2.488 & 55.54 & $* \star *$ & 0.955 & 0.130 & 2.598 & 54.01 & $* * \star$ \\
\hline $\begin{array}{l}\text { Attitude towards financial } \\
\text { service risk }\end{array}$ & -0.103 & 0.107 & 0.902 & 0.924 & & -0.113 & 0.113 & 0.894 & 0.996 & \\
\hline Financial advice & 0.199 & 0.110 & 1.220 & 3.278 & * & 0.144 & 0.115 & 1.155 & 1.567 & \\
\hline Attitude towards payment risk & -0.188 & 0.105 & 0.828 & 3.244 & * & -0.253 & 0.110 & 0.777 & 5.307 & ** \\
\hline Attitude towards risk tolerance & -0.282 & 0.109 & 0.755 & 6.615 & *** & -0.232 & 0.113 & 0.793 & 4.173 & ** \\
\hline Financial attitude & -0.110 & 0.102 & 0.896 & 1.162 & & -0.112 & 0.106 & 0.894 & 1.102 & \\
\hline Prior bank experience & & & & & & & & & 14.06 & *** \\
\hline Less than 1 year & & & & & & -1.651 & 0.560 & 0.192 & 8.699 & *** \\
\hline $1-2$ years & & & & & & -0.381 & 0.439 & 0.683 & 0.753 & \\
\hline $3-5$ years & & & & & & -0.794 & 0.371 & 0.452 & 4.591 & ** \\
\hline $5-10$ years & & & & & & -0.117 & 0.366 & 0.890 & 0.101 & \\
\hline Model test/statistic & & $x^{2}$ & $d f$ & Sig. & & & $x^{2}$ & $d f$ & Sig. & \\
\hline Omnibus test & & 237.9 & 22 & 0.000 & & & 252.6 & 26 & 0.000 & \\
\hline Hosmer \& Lemeshow test & & 4.090 & 8 & 0.849 & & & 13.39 & 8 & 0.099 & \\
\hline -2Log likelihood & 611.4 & & & & & 575.5 & & & & \\
\hline
\end{tabular}




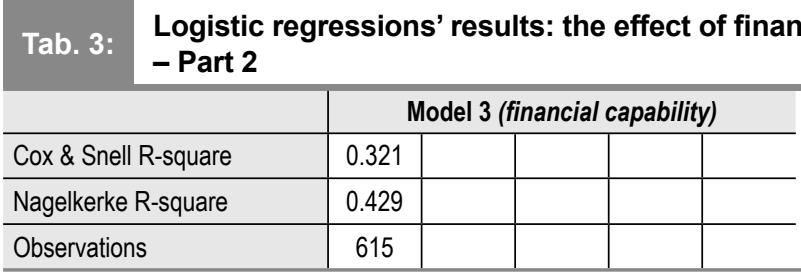

\begin{tabular}{c|l|l|l|l}
\multicolumn{5}{c}{ Model 4 (prior bank experience) } \\
\hline 0.344 & & & & \\
\hline 0.459 & & & & \\
\hline 599 & & & & \\
\hline
\end{tabular}

Source: own

Note: ${ }^{*},{ }^{* *}$, and ${ }^{* * *}$ stand for $90 \%, 95 \%$ and $99 \%$ significance level. Levels of income are compared to Income above $100,000 \mathrm{ALL}$, occupation categories are compared to other, education levels are compared to the university one, prior bank experience levels are compared to more than 10 years.

augmentation of Model 2, which include the effect of financial capability on the online purchase decision. It revealed that four out of the six factors of financial capability predicted an individual's online purchase decision. The chances to purchase online were increased by digital banking usage $\left(X^{2}=55.54\right.$, OR $=2.488$, $p<0.01)$ and financial advice $\left(X^{2}=3.278\right.$, OR $=1.220, p<0.10)$, and decreased by attitude towards payment risk $\left(X^{2}=3.244\right.$, OR $=0.828, p<0.10)$ and attitude towards risk tolerance $\left(X^{2}=6.615\right.$, OR $\left.=0.755, p<0.01\right)$. Thus, H1a, H1c, H1d and H1e were supported. Concerning technology use variables, Model 3 showed similar results with the Model 2, so $\mathrm{H} 3$ and $\mathrm{H} 4$ were supported. However, among all control variables, only income level resulted to be statistically significant in Model 3 . Thus, the higher the level of income, the higher were the chances that individuals get involved in online purchasing.

To investigate whether prior bank experience effects online shopping or not, another logistic regression was run (see Model 4). According to its results, prior bank experience predicted online shopping, $X^{2}=14.06, p<0.01$. In more details, compare to those who had more than ten years as a client of a bank, individuals with less than one year of prior bank experience $\left(X^{2}=8.699, \mathrm{OR}=0.192, p<0.01\right)$ and those who had three to five years of experience $\left(X^{2}=4.591\right.$, $\mathrm{OR}=0.452, p<0.05)$ had statistically lower chances to purchase online. Therefore, $\mathrm{H} 2$ was supported. Among the factors covering financial capability, which significantly influenced on online purchase, were digital banking usage $\left(X^{2}=54.01, \mathrm{OR}=2.598, p<0.01\right)$, payment risk $\left(X^{2}=5.307, O R=0.777, p<0.05\right)$ and risk tolerance $\left(X^{2}=4.173\right.$, OR $\left.=0.793, p<0.05\right)$. Thus, H1a, H1d and H1e were supported. No evidence was found to support $H 1 b$ and
H1f. Again, technology use was reported to be significant in predicting online shopping: possessing a smartphone $\left(X^{2}=16.54\right.$, OR $=10.87, p<0.01)$ and using social media $\left(X^{2}=4.285, \mathrm{OR}=4.504, p<0.05\right)$. As a result, $\mathrm{H} 3$ and $\mathrm{H} 4$ were supported.

The assumptions of the logistic regressions were not violated. All predictors significantly distinguished between those who purchase online and those who do not, as Omnibus test revealed, which are consistent with the results of Hosmer and Lemeshow's test. According to the Nagelkerke R-square, the effect size increased 2.6 times from baseline model $(0.176)$ to Model 4 (0.459), indicating the importance of financial capability components in explaining the variation of the dependent variable.

\section{Discussion}

In this study, it is hypothesized that individuals' financial capability influences on online purchasing. Based on Sen's capability theory (1993), this study firstly identified six dimensions of financial capability in the online context, such as digital banking usage, financial advice, financial service risk, payment risk, risk tolerance, and financial attitude. A certain level of financial capability can affect the chances an individual performs online purchases. Indeed, our analysis revealed that individuals who used digital banking and consulted their financial matters with others (i.e. with professionals, family members or friends) were more prone to purchase through online channels. These findings are consistent with Sherraden's (2013) arguments which enforce the idea that financially capable people have access to financial services, and by using them, they are more likely to perform online payments and, consequentially, online purchases. Regarding financial advice (Calcagno \& Monticone, 2015; 
Kramer, 2016; Marsden et al., 2011), our results demonstrated the importance of consulting the financial issues on deciding to perform online purchases. Thus, an individual who consults or seeks advice on financial matters has higher chances to purchase via online channels.

Our analysis did not find evidence to support the effect of financial attitude on online shopping. This insignificant relationship is in line with a prior study (Pham et al., 2012), which underlines that financial attitude is not important for compulsive buying after controlling for materialism. In terms of payment risk and risk tolerance, results indicated that they negatively influence on individuals' online purchasing. These findings are consistent with the general knowledge concerning risk, which is identified by scholars as a crucial factor for e-service acceptance and with a negative influence on individuals' online purchasing (Barbaranelli, Guidugli, Di Giorgio, \& Gramazio, 2015; Kamalul Ariffin, Mohan, \& Goh, 2018; Kim et al., 2008; Mou et al., 2017).

The current research found that the use of technology positively affects online purchasing. Both, using a smartphone and having a social media account increase the chances an individual to involve in online purchasing. Our findings are consistent with Pucci et al. (2019) study, which emphasizes the positive impact of social media usage on online purchase intentions. Additionally, the smartphone is becoming central to consumer everyday lives, the study indicated that consumers who used smartphone tend to make actual purchasing decisions. This finding is consistent with Groß (2015), which indicated the acceptance of smartphone usage for mobile shopping.

As it was expected, online purchasing is positively affected by prior bank experience. Individuals who have more than ten years with the bank demonstrated higher chances to involve in online purchasing. This goes in line with Karjaluoto, Mattila and Pento's (2002) findings that internet banking usage is positively influenced by personal bank experience, but contradicts with Oertzen and OdekerkenSchröder (2019) study, as they failed to find any statistical significance between one's years with the bank and continuing usage in online banking.

Regarding practical implication, the bank managers should consider the digital bank services as part of their policy which may lead to cost reduction since to perform certain transaction individuals do not need to go physically to the bank branches. The bank staff can demonstrate to clients how to perform such things remotely. By having a clear view on how to influence online purchase with financial capability, policymakers may adjust policies to achieve higher results in enriching individuals with sound financial capability that are needed in modern times. In this context, the triple helix model (Kim, Kim, \& Yang, 2012) may be used to increase, firstly, individuals' financial capability level, and then their online purchasing engagement. Based on this model, the way how government, education system, and private sector harmonise the policies can motivate individuals to involve in business activity. This principle can be applied even in the case of online shopping. For example, banks in some European countries have developed partnerships with local educational institutions by introducing in an initiative based on the online management and virtual portfolio of securities. By doing so, young individuals can learn and understand financial economics and markets, and experience investing in securities (OECD, 2016). Indeed, similar to the Bank of Italy, Bank of Albania has introduced a special program dealing with financial literacy. However, it is recommended to extend this program by including other institutions and industry as well and covering all age-groups of the population.

The digital banking situation varies among the Western Balkan countries. Croatia is performing better than the other Balkan states, as the digital banking penetration was $86 \%$, followed by Serbia with $37 \%$. The lowest level is recorded for Albania and Montenegro with $11 \%$ each. The number of transactions completed by using digital banking in a year is low for Albania, Kosovo, North Macedonia and Montenegro. However, they are increasing from one year to another. For example, Albania increased the volume of these transactions by $60 \%$ from 2016 to 2017. Technological advancement through electronic and mobile banking can be useful to remove cash and paper-based transactions and can reduce the cost significantly and can help banking services expansion in Albania. Moreover, initiatives on access and usage will complement the other initiatives such as to enhance financial literacy among Albanians (Bank of Albania, 2018). But the studies on digital banking usage and acceptance in the 
context of a transition country like Albania is still limited and emerging studies can contribute theoretically for its practical implication and improvement. Apparently, this is one of the reasons to conduct this study in the premises of Albania. Recently, considerable progress has been observed regarding the number of homebanking transactions amplified substantially during 2018 (Bank of Albania, 2019) and it an obvious motivation of study. To sum up, all indications of the fast development trend of technology acceptance and usage in Albania, mobile banking seems a burgeoning area to be researched and recommend.

It is widely recognised that with the rise of online purchasing and service delivery, security, trust and individuals' perceived risk became essential issues for online behaviour (Changchit, Cutshall, Lonkani, Pholwan, \& Pongwiritthon, 2019; Mbama et al., 2018; Mou et al., 2017; Patro, 2018; Phan \& Pilík, 2018; Phan, Rivas, \& Bat, 2019). The current study identified payment risk and risk tolerance as determinants of individuals' online purchase behaviour. Thus, to benefit in terms of the trade volume, online retailers must take consumers' perceived risk into account and extra efforts should be needed to address it properly.

\section{Conclusions}

Recently, scholars have paid attention to the online purchase topic by shedding light over its influencing factors. The current research provides useful insights concerning the determinants of online purchasing by combining individuals' financial capability, technology and social media usage along with its demographic characteristics. To the best of our knowledge, this is among the first studies filling this gap in the literature. By bridging the abovementioned perspectives, this study contributes to a better understanding of the online shopping puzzle.

This research aims to facilitate the understanding of online consumer behaviour. Our evidence supports the argument that individuals' financial capabilities, such as having access to bank services, using digital banking and consulting financial matters with professionals, family members or friends, increase the chances an individual to engage in online purchase activity. We consider this as a unique value or contribution of this paper for both theoretical and practical implications. Therefore, individuals' financial capability should be considered as a predictor of online purchase behaviour, which imposes the adjustments of current theoretical models introduced by scholars to explain it. In light of our results, a new conceptual model can be proposed. Hence, online purchase behaviour traditionally is determined by attitude, social norms, perceived risk, trust, technology adoption, social media usage, etc. The current paper suggests a new conceptual framework, which includes even the level of the individuals' financial capability. Being financially capable lead to higher chances an individual performs financial transactions remotely (online shopping), thus emphasizing the critical role of its implementation. The study contributes to a better understanding of the determinants of consumer actual behaviour, so customers would continue purchasing online.

From a managerial point of view, this study provides guidelines to e-vendors for better definitions of their marketing strategies. Specifically, service providers are in favour of promoting services remotely, as it reduces operational costs. New technological adoption gives competitive advantages by enabling firms to improve services. Service providers in transition countries are advised to follow the trends in advanced economies regarding digital banking services as it has benefits for firms and clients. Moreover, the results of this research assist suggest to the vendors to adjust their strategies based on the individuals' technology usage. Therefore, from the marketing point of view, consumers' segmentation can be applied to leverage the activity.

Additionally, the results of this study provide convergent evidence that social media and smartphone are significant variables in predicting actual purchasing behaviour. It is of big importance to note that technology developers should improve the performance and convenience attributes of their products/ services to offering a reliable and secure environment at anytime and anywhere with the use of smartphones. Furthermore, online vendors bring their products/services closer to potential consumers through social media platforms, such as Facebook, Instagram, Twitter, etc.

Although the study has reached its aim, there are limitations to the research. Nonetheless, Albania might have similar conditions compared to other countries concerning technological 
and economic progress, the findings of this research are limited to one country. Second, a more comprehended theoretical model could be condenser including other factors such as trust and benefits.

\section{References}

Ajzen, I. (1991). The theory of planned behavior. Organizational Behavior and Human Decision Processes, 50(2), 179-211. https://doi.org/10.1016/0749-5978(91)90020-T

Al-Debei, M. M., Akroush, M. N., \& Ashouri, M. I. (2015). Consumer attitudes towards online shopping: the effects of trust, perceived benefits, and perceived web quality. Internet Research, 25(5), 707-733. https://doi.org/10.1108/IntR05-2014-0146

Atkinson, A., McKay, S., Kempson, E., \& Collard, S. (2006). Levels of financial capability in the UK: Results of a baseline survey. London: Financial Services Authority.

Bank of Albania. (2018). The Retail Payment Costs and Savings in Albania. Tiranë: Bank of Albania.

Bank of Albania. (2019). Homebanking transactions 2005-2019. Tiranë: Bank of Albania.

Barbaranelli, C., Guidugli, S. P., Di Giorgio, D., \& Gramazio, M. (2015). Personal determinants of purchasing of pharmaceutical products online. TPM - Testing, Psychometrics, Methodology in Applied Psychology, 22(1), 3-21. https://doi.org/10.4473/TPM22.1.1

Belás, J., Cipovová, E., \& Demjan, V. (2014). Current Trends in Area of Satisfaction of Bank Clients in the Czech Republic and Slovakia. Transformations in Business \& Economics, 13(3), 219-234.

Belás, J., \& Gabčová, L. (2016). The relationship among customer satisfaction, loyalty and financial performance of commercial banks. E\&M Economics and Management, 19(1), 132147. https://doi.org/10.15240/tul/001/2016-1-010

Bilgihan, A., \& Kandampully, J. (2016). Towards a unified customer experience in online shopping environments: Antecedents and outcomes. International Journal of Quality and Service Sciences, 8(1), 102-119. https:// doi.org/10.1108/IJQSS-07-2015-0054

Calcagno, R., \& Monticone, C. (2015). Financial literacy and the demand for financial advice. Journal of Banking \& Finance, 50, 363-380. https://doi.org/10.1016/j. jbankfin.2014.03.013
Çera, G., \& Tuzi, B. (2019). Does gender matter in financial literacy? A case study of young people in Tirana. Scientific Papers of the University of Pardubice, Series D, 45(1), 5-16. Retrieved from https://dk.upce.cz/ handle/10195/72241

Changchit, C., Cutshall, R., Lonkani, R., Pholwan, K., \& Pongwiritthon, R. (2019). Determinants of Online Shopping Influencing Thai Consumer's Buying Choices. Journal of Internet Commerce, 18(1), 1-23. https://doi.or $\mathrm{g} / 10.1080 / 15332861.2018 .1496391$

Collard, S. (2019). Book review: Financial Capability and Asset Building in Vulnerable Households: Theory and Practice, Margaret S. Sherraden, Julie Birkenmaier, J. Michael Collins. Journal of Economic Psychology, 72, 45-46. https://doi.org/10.1016/j.joep.2019.01.005

CRITEO. (2018). Mobile Commerce Growth 2017. Retrieved July 10, 2019, from https://www. criteo.com/insights/mobile-commerce-q4-2017/

Davis, F. D. (1989). Perceived Usefulness, Perceived Ease of Use, and User Acceptance of Information Technology. MIS Quarterly, 13(3), 319-340. https://doi.org/10.2307/249008

Despard, M. R., \& Chowa, G. A. (2014). Testing a Measurement Model of Financial Capability Among Youth in Ghana. Journal of Consumer Affairs, 48(2), 301-322.

Duroy, D., Gorse, P., \& Lejoyeux, M. (2014). Characteristics of online compulsive buying in Parisian students. Addictive Behaviors, 39(12), 1827-1830. https://doi.org/10.1016/j. addbeh.2014.07.028

Estelami, H., \& De Maeyer, P. (2010). An exploratory study of divided pricing effects on financial service quality expectations. Journal of Financial Services Marketing, 15(1), 19-31. https://doi.org/10.1057/fsm.2010.4

Gibreel, O., AlOtaibi, D. A., \& Altmann, J. (2018). Social commerce development in emerging markets. Electronic Commerce Research and Applications, 27, 152-162. https://doi.org/10.1016/j.elerap.2017.12.008

Groß, M. (2015). Exploring the acceptance of technology for mobile shopping: an empirical investigation among Smartphone users. International Review of Retail, Distribution and Consumer Research, 25(3), 215-235. https://doi.org/10.1080/09593969.2014.988280

Hamidi, N., Rad, T. T., \& Jahany, A. (2012). Evaluation of Factors Influencing Tendency Towards E-Banking In Bank Customers. Far East Journal of Marketing and Management, 
2(3), 25-42. Retrieved from https://ideas.repec. org/a/fej/artcal/v2by2012i3p25-42.html

Hosmer, D. W., Lemeshow, S., \& Sturdivant, R. X. (2013). Applied logistic regression. (3rd ed.). New York, NY: Wiley.

Hove, L. Van, \& Karimov, F. P. (2016). The role of risk in e-retailers' adoption of payment methods: evidence for transition economies. Electronic Commerce Research, 16(1), 27-72. https://doi.org/10.1007/s10660-015-9203-6

Hubert, M., Blut, M., Brock, C., Backhaus, C., \& Eberhardt, T. (2017). Acceptance of Smartphone-Based Mobile Shopping: Mobile Benefits, Customer Characteristics, Perceived Risks, and the Impact of Application Context. Psychology \& Marketing, 34(2), 175-194. https://doi.org/10.1002/mar.20982

Huston, S. J. (2010). Measuring Financial Literacy. Journal of Consumer Affairs, 44(2), 296-316. https://doi.org/10.1111/j.17456606.2010.01170.x

Joo, S. H., \& Grable, J. E. (2004). An Exploratory Framework of the Determinants of Financial Satisfaction. Journal of Family and Economic Issues, 25(1), 25-50. https://doi. org/10.1023/B:JEEI.0000016722.37994.9f

Kamalul Ariffin, S., Mohan, T., \& Goh, Y. N. (2018). Influence of consumers' perceived risk on consumers' online purchase intention. Journal of Research in Interactive Marketing, 12(3), 309-327. https://doi.org/10.1108/JRIM11-2017-0100

Kaplan, A. M., \& Haenlein, M. (2010). Users of the world, unite! The challenges and opportunities of Social Media. Business Horizons, 53(1), 59-68. https://doi. org/10.1016/j.bushor.2009.09.003

Karjaluoto, H., Mattila, M., \& Pento, T. (2002). Factors underlying attitude formation towards online banking in Finland. International Journal of Bank Marketing, 20(6), 261-272. https://doi.org/10.1108/02652320210446724

Katawetawaraks, C., \& Wang, C. L. (2011). Online Shopper Behavior: Influences of Online Shopping Decision. Asian Journal of Business Research, 1(2), 66-74. https://doi. org/10.14707/ajbr.110012

Kempson, E., Collard, S., \& Moore, N. (2005). Measuring financial capability: An exploratory study (Consumer Research Report 37). Bristol: Financial Services Authority.

Kim, D. J., Ferrin, D. L., \& Rao, H. R. (2008). A trust-based consumer decision-making model in electronic commerce: The role of trust, perceived risk, and their antecedents. Decision Support Systems, 44(2), 544-564. https://doi. org/10.1016/j.dss.2007.07.001

Kim, Y., Kim, W., \& Yang, T. (2012). The effect of the triple helix system and habitat on regional entrepreneurship: Empirical evidence from the U.S. Research Policy, 41(1), 154-166. https://doi.org/10.1016/J.RESPOL.2011.08.003

Kramer, M. M. (2016). Financial literacy, confidence and financial advice seeking. Journal of Economic Behavior \& Organization, 131(A), 198-217. https://doi.org/10.1016/J. JEBO.2016.08.016

Lam, L. T., \& Lam, M. K. (2017). The association between financial literacy and Problematic Internet Shopping in a multinational sample. Addictive Behaviors Reports, 6, 123-127. https://doi.org/10.1016/j. abrep.2017.10.002

Laroche, M., Habibi, M. R., \& Richard, M.-O. (2013). To be or not to be in social media: How brand loyalty is affected by social media? International Journal of Information Management, 33(1), 76-82. https://doi. org/10.1016/j.ijinfomgt.2012.07.003

Lusardi, A., \& Mitchell, O. S. (2014). The Economic Importance of Financial Literacy: Theory and Evidence. Journal of Economic Literature, 52(1), 5-44. https://doi.org/10.1257/ jel.52.1.5

Marsden, M., Zick, C. D., \& Mayer, R. N. (2011). The Value of Seeking Financial Advice. Journal of Family and Economic Issues, 32(4), 625-643. https://doi.org/10.1007/s10834-0119258-z

Mbama, C. I., Ezepue, P., Alboul, L., \& Beer, M. (2018). Digital banking, customer experience and financial performance. Journal of Research in Interactive Marketing, 12(4), 432-451. https://doi.org/10.1108/jrim-01-20180026

MCEETYA. (2011). National Consumer and Financial Literacy Framework. Ministerial Council on Education, Employment, Training and Youth Affairs. Melbourne Declaration on Educational Goals for You.

McKay, S. (2011). Understanding Financial Capability in Canada: Analysis of the Canadian Financial Capability Survey. Task Force on Financial Literacy.

Mehrabian, A., \& Russell, J. (1974). An approach to environmental psychology. The MIT Press. Retrieved from https://psycnet.apa. org/record/1974-22049-000 
Mikalef, P., Giannakos, M., \& Pateli, A. (2013). Shopping and Word-of-Mouth Intentions on Social Media. Journal of Theoretical and Applied Electronic Commerce Research, 8(1), 17-34. https://doi.org/10.4067/S071818762013000100003

Mou, J., Shin, D. H., \& Cohen, J. F. (2017). Trust and risk in consumer acceptance of e-services. Electronic Commerce Research, 17(2), 255-288. https://doi.org/10.1007/ s10660-015-9205-4

Naseri, M. B., \& Elliott, G. (2011). Role of demographics, social connectedness and prior internet experience in adoption of online shopping: Applications for direct marketing. Journal of Targeting, Measurement and Analysis for Marketing, 19(2), 69-84. https://doi.org/10.1057/jt.2011.9

Negash, S., Meso, P., \& Wiredu, G. (2011). Mobile Banking Adoption in the United States: Adapting mobile banking features from lowincome countries. In $A$ proceeding of SIG GlobDev Fourth Annual Workshop (pp. 1-6). Retrieved from http://citeseerx.ist.psu.edu/ viewdoc/download?doi=10.1.1.688.2614\&rep= rep1\&type=pdf

Nguyen, T. A. N., \& Rozsa, Z. (2019). Financial Literacy and Financial Advice Seeking for Retirement Investment Choice. Journal of Competitiveness, 11(1), 70-83. https://doi. org/10.7441/joc.2019.01.05

OECD. (2016). Financial Education in Europe: Trends and Recent Developments. Paris: OECD Publishing. https://doi. org/10.1787/9789264254855-en

Oertzen, A. S., \& Odekerken-Schröder, G. (2019). Achieving continued usage in online banking: a post-adoption study. International Journal of Bank Marketing, 37(6), 1394-1418. https://doi.org/10.1108/lJBM-09-2018-0239

Oluwafemi, O. J., \& Adebiyi, S. O. (2018). Customer Loyalty and Integrated Marketing Communications among Subscribers of Telecommunication Firms in Lagos Metropolis, Nigeria. Journal of Competitiveness, 10(3), 101118. https://doi.org/10.7441/joc.2018.03.07

Pan, L. Y., \& Chiou, J. S. (2011). How Much Can You Trust Online Information? Cues for Perceived Trustworthiness of Consumergenerated Online Information. Journal of Interactive Marketing, 25(2), 67-74. https://doi. org/10.1016/j.intmar.2011.01.002

Patro, C. S. (2018). Predicting Consumers' Acceptance of Online Shopping on the Internet.
International Journal of Cyber Behavior. Psychology and Learning, 8(1), 33-60. https://doi.org/10.4018/IJCBPL.2018010103

Pham, T. H., Yap, K., \& Dowling, N. A. (2012). The impact of financial management practices and financial attitudes on the relationship between materialism and compulsive buying. Journal of Economic Psychology, 33(3), 461-470. https://doi.org/10.1016/j.joep.2011.12.007

Phan, Q. P. T., \& Pilík, M. (2018). The relationship between website design and positive ewom intention: Testing mediator and moderator effect. Journal of Business Economics and Management, 19(2), 382-398. https://doi.org/10.3846/jbem.18.5690

Phan, Q. P. T., Rivas, A. A. A., \& Bat, T. (2019). Analyzing Electronic Word of Mouth Intention for Shopping Websites: A Means-End Chain Approach. Journal of Internet Commerce, 18(2), 113-140. https://doi.org/10.1080/153328 61.2019.1595361

Prasad, S., \& Sharma, M. (2016). Demographic and Socioeconomic Influences Shaping Usage of Online Channel for Purchase of Food \& Grocery. Indian Journal of Marketing, 46(10), 7-21. Retrieved from http://www. indianjournalofmarketing.com/index.php/ijom/ article/view/102851

Pucci, T., Casprini, E., Nosi, C., \& Zanni, L. (2019). Does social media usage affect online purchasing intention for wine? The moderating role of subjective and objective knowledge. British Food Journal, 121(2), 275-288. https://doi.org/10.1108/BFJ-06-2018-0400

Punj, G. (2011). Effect of consumer beliefs on online purchase behavior: The influence of demographic characteristics and consumption values. Journal of Interactive Marketing, 25(3), 134-144. https://doi.org/10.1016/j.intmar.2011. 04.004

Sen, A. (1993). Does Business Ethics Make Economic Sense? Business Ethics Quarterly, 3(1), 53-66. https://doi.org/10.1007/978-94-0158165-3_6

Shechter, R. (2017). Mobile Shopping: The New Norm. Retrieved from https://www. theleverageway.com/blog/mobile-onlineshopping-new-norm/

Sherraden, M. S. (2013). Building Blocks of Financial Capability. In J. Birkenmaier, M. Sherraden, \& J. Curley (Eds.), Financial Capability and AssetDevelopment (pp. 3-43). New York, NY: Oxford University Press. https://doi.org/10. 1093/acprof:oso/9780199755950.003.0012 
Shkvarchuk, L., \& Slav'yuk, R. (2019). The Financial Behavior of Households in Ukraine. Journal of Competitiveness, 11(2), 144-159. https://doi.org/10.7441/joc.2019.03.09

Silva, J., Pinho, J. C., Soares, A., \& Sá, E. (2019). Antecedents of online purchase intention and behaviour: Uncovering unobserved heterogeneity. Journal of Business Economics and Management, 20(1), 131-148. https://doi.org/10.3846/jbem.2019.7060

Smith, R., Deitz, G., Royne, M. B., Hansen, J. D., Grünhagen, M., Witte, C., \& Heller, W. E. (2013). Cross-cultural examination of online shopping behavior: A comparison of Norway, Germany, and the United States. Journal of Business Research, 66(3), 328-335. https://doi.org/10.1016/j.jbusres.2011.08.013

Suchanek, P., \& Kralova, M. (2018). The Influence of Costumers' Personal Characteristics on their Satisfaction with the Food Industry. Journal of Competitiveness, 10(4), 151-170. https://doi.org/10.7441/ joc.2018.04.10

Tabachnick, B. G., \& Fidell, L. S. (2013). Using multivariate statistics (6th ed.). Boston, MA: Pearson Education.

Taylor, M. (2011). Measuring Financial Capability and its Determinants Using Survey Data. Social Indicators Research, 102(2), 297-314. https://doi.org/10.1007/s11205-0109681-9
Voropanova, E. (2015). Conceptualizing smart shopping with a smartphone: implications of the use of mobile devices for shopping productivity and value. International Review of Retail, Distribution and Consumer Research, 25(5), 529-550. https://doi.org/10.1080/09593 969.2015.1089304

Vyvyan, V., Blue, L., \& Brimble, M. (2014). Factors that Influence Financial Capability and Effectiveness: Exploring Financial Counsellors' Perspectives. Australasian Accounting, Business and Finance Journal, 8(4), 3-22. https://doi.org/10.14453/aabfj.v8i4.2

Wagner, G., Schramm-Klein, H., \& Steinmann, S. (2013). Effects of crosschannel synergies and complementarity in a multichannel e-commerce system - an investigation of the interrelation of e-commerce, m-commerce and IETV-commerce. The International Review of Retail, Distribution and Consumer Research, 23(5), 571-581. https://doi.org/10.1080/09593969.2013.832697

Wu, W.-Y., \& Ke, C.-C. (2015). An Online Shopping Behavior Model Integrating Personality Traits, Perceived Risk, and Technology Acceptance. Social Behavior and Personality: An International Journal, 43(1), 85-97. https:// doi.org/10.2224/sbp.2015.43.1.85

Xiao, J. J., Chen, C., \& Chen, F. (2014). Consumer financial capability and financial satisfaction. Social Indicators Research, 118(1), 415-432. https://doi.org/10.1007/s11205-0130414-8 